\title{
Ion amount in Zoysia matrella Merr. leaves during the winter season in the saline environments
}

\section{SUGIURA, Souichirou $^{* 1)}$ and TAKAHASHI, Shimpei ${ }^{2)}$}

\author{
1) Graduate School of Agriculture, Tokyo University of Agriculture
}

東京農業大学大学院 農学研究科

2) Faculty of Regional Environment Science, Tokyo University of Agriculture

東京農業大学 地域環境科学部

\begin{abstract}
The purpose of the present study was to evaluate the ion amounts characteristics of green leaves and brown leaves in Zoysia matrella (L.) Merr. during the winter season in the saline environments. Plants were treated with four concentrations of $\mathrm{NaCl}$ solution $(0,7.5,15$ and $30 \mathrm{~g} / \mathrm{L} \mathrm{NaCl})$ for 165 days during the winter season. In the $30 \mathrm{~g} / \mathrm{L} \mathrm{NaCl}$ group, all leaves turned brown (leaf mortality ratio was $100 \%$ ). In the 7.5 and $15 \mathrm{~g} / \mathrm{L}$ $\mathrm{NaCl}$ groups, $\mathrm{Na}^{+}$amounts of brown leaves were 1.4-fold and 2.0-fold higher than in green leaves, respectively. Furthermore, in the 7.5 and $15 \mathrm{~g} / \mathrm{L} \mathrm{NaCl}$ groups, $\mathrm{Cl}^{-}$amounts of brown leaves were 1.4-fold and 2.0-fold higher than in green leaves, respectively. However, $\mathrm{K}^{+}$amount exhibited an inverse relationship, with higher $\mathrm{K}^{+}$ amount in green leaves than in brown leaves. In the $0,7.5$, and $15 \mathrm{~g} / \mathrm{L} \mathrm{NaCl}$ groups, $\mathrm{K}^{+}$amounts of green leaves were 2.3-fold, 1.8fold, and 1.8-fold higher than in brown leaves, respectively. Furthermore, the results of $\mathrm{K}^{+} / \mathrm{Na}^{+}$ ratio in the green leaves showed higher value compared with brown leaves with significant difference in $7.5 \mathrm{~g} / \mathrm{L}$ (2.4-fold higher) and $15 \mathrm{~g} / \mathrm{L}$ (3.5-fold higher) $\mathrm{NaCl}$ treated groups. From the results of completely different traits in ion amount and $\mathrm{K}^{+} / \mathrm{Na}^{+}$ratio in green and brown leaves indicated that $Z$. matrella could accumulate harmful $\mathrm{NaCl}$ in senescing leaves against salinity stress in the winter season.
\end{abstract}

Key words: salt tolerant turf grass, green leaves, brown leaves, sodium ion, potassium ion, $\mathrm{K}^{+} / \mathrm{Na}^{+}$ratio

杉浦総一郎・高橋新平 : 冬季塩分環境下におけるコウライシバ (Zoysia matrella Merr.) 葉身部のイオン濃度 摘要 : 冬季塩分環境下におけるコウライシバ (Zoysia matrella (L.) Merr.) の健全葉および枯死葉のイオン濃度 特性を明らかにするため, 冬季 165 日間にわたり本種に 4 段階の $\mathrm{NaCl}$ 溶液 $[0 \mathrm{~g} / \mathrm{L}$ (Control), $7.5 \mathrm{~g} / \mathrm{L}, 15 \mathrm{~g}$ / $\mathrm{L} ， 30 \mathrm{~g} / \mathrm{L}$ 〕を施用した。その結果， $30 \mathrm{~g} / \mathrm{L}$ 区では，全ての葉身部の枯死が確認された（枯死率 $100 \%) 。$ 葉身部 の $\mathrm{Na}^{+}$濃度は健全葉より枯死葉で高く, $7.5 \mathrm{~g} / \mathrm{L}$ 区で 1.4 倍, $15 \mathrm{~g} / \mathrm{L}$ 区で 2.0 倍高い值であった。 $\mathrm{Cl}^{-}$濃度も同様 に枯死葉で高い值を示し, $7.5 \mathrm{~g} / \mathrm{L}$ 区で 1.4 倍, $15 \mathrm{~g} / \mathrm{L}$ 区で 2.0 倍，健全葉より高い值を示した。一方， $\mathrm{K}^{+}$濃度 は健全葉で高く, Control 区で 2.3 倍, $7.5 \mathrm{~g} / \mathrm{L}$ 区で 1.8 倍, $15 \mathrm{~g} / \mathrm{L}$ 区で 1.8 倍, 枯死葉より高い值を示し, $\mathrm{Na}^{+}, \mathrm{Cl}^{-}$濃度と逆の傾向を示した。さらに, $\mathrm{K}^{+} / \mathrm{Na}^{+}$比は, 枯死葉より健全葉で高く, $7.5 \mathrm{~g} / \mathrm{L}$ 区, $15 \mathrm{~g} / \mathrm{L}$ 区に おいてそれぞれ 2.4 倍, 3.5 倍高い值を示した。枯死葉と健全葉のイオン濃度と $\mathrm{K}^{+} / \mathrm{Na}^{+}$比に明らかな違いが見 られたことから，コウライシバは枯死に至る前の老化した葉に多くの $\mathrm{Na}^{+}, \mathrm{Cl}^{-}$を蓄積させることで, 冬季にお ける塩ストレスに対応していると考えられた。

キーワード：耐塩性芝草, 健全葉, 枯死葉, ナトリウムイオン, カリウムイオン, $\mathrm{K}^{+} / \mathrm{Na}^{+}$比

\section{Introduction}

Zoysia matrella (L.) Merr. is a popular and common turf grass used as a ground cover plant for green spaces in Japan (Asano \& Namihisa, 1999; Fukuoka, 2000). This turf grass also has been recognized as salt-tolerant species (Marcum, 2006; Uddin et al., 2009). Regarding salt tolerance of $Z$. $m a$ trella, salt excretion from salt gland and leaf surface (Yamamoto et al., 2016; Sugiura, 2020), salt compartment in the vacuole (Chen et al., 2015) and osmotic adjustment in cells (Marcum \& Murdoch, 1994; Akamine et al., 2002) have been reported. For the characteristics of salt tolerance, the species has been noticed as cost efficient turf grass in landscape area with saline water irrigation (Chen et al., 2009), and it was also considered important greening plants for coastal area with storm surge or tsunami damage may occur.

However, the plant leaves die (turn to brown) in the winter season (new leaves develop from the surviving rhizomes in the spring season). Furthermore, the species is called

\footnotetext{
* Corresponding author (連絡先著者)： ₹ 156-8502 1-1-1 Sakuragaoka, Setagaya-ku, Tokyo, Japan

E-mail : s11292614@yahoo.co.jp
} 
warm-season turfgrass, delicate for low temperature stress, the optimum temperature is $25^{\circ} \mathrm{C}-35^{\circ} \mathrm{C}$ (Sato, 1995). For utilizing the turf grass sustainably in saline environments such as coastal area, the salinity stress tolerance mechanism in winter season of $Z$. matrella was considered important to understand.

It has been known that the senescing leaves have important role in plants physiology in winter season. Generally for ion reuse, deciduous trees undergo ion translocation from the leaves in the winter season prior to the leaves dying and falling. A prior study reported that in Quercus serrata, leaves exhibit low ion amount, including nitrogen, phosphate, potassium and magnesium, in the winter season (Hiraizumi et al., 1996). Especially, potassium is an important ion for osmotic control and tolerance of environmental stress for plants (Turgeon, 2007). Moreover, it was referred that turfgrass undergoes leaf amino acid translocation as the process of leaves dying (Turgeon, 2007).

Senescing leaves also have an important role in plant salinity stress tolerance. Previous reports indicated that the salt tolerant species can accumulate $\mathrm{NaCl}$ in leaves, which then die and fall, removing harmful salt (Imada et al., 2009; Kanai et al., 2014). It was demonstrated that $Z$. matrella accumulate large amounts of salt in its leaves compare with other parts of the plant (rhizomes and roots) in saline environments (Sugiura et al., 2017).

From the above, we hypothesized that $Z$. matrella senescing leaves have important role for salinity stress tolerance in winter season as accumulating salinity in senescing leaves. However, there is presently no report evaluating ion amounts of senescing leaves in herbaceous plant including Z. matrella with detailed quantitative data. Therefore it considered valuable to clarify ion amounts in brown leaves for understand the plants physiology and strategy for salinity stress in low temperature stress.

To clarify ion amount of brown leaves, we treated $Z$. $m a$ trella with different concentrations of $\mathrm{NaCl}$ solution during the winter season, and measured ion amount $\left(\mathrm{Na}^{+}, \mathrm{Cl}^{-}\right.$and $\mathrm{K}^{+}$) in green leaves and brown leaves, together with leaf mortality ratio and $\mathrm{K}^{+} / \mathrm{Na}^{+}$ratio. The objective of the present study was to evaluate ion amount characteristics in green and brown leaves in a saline environment during the winter season, and to understand the role of senescing leaves for salinity stress.

\section{Materials and Methods}

\subsection{Species and experimental design}

Zoysia matrella (L.) Merr. was purchased as sod turf from the Tottori Lawn Product Association (Tottori, Japan). On June 7,2015 , three stolon segments $(3 \mathrm{~cm} /$ each) were planted in $200 \mathrm{~cm}^{2}$ Wagner pots filled with $1.0 \mathrm{~kg}$ gravel as a drainage layer and $4.0 \mathrm{~kg}$ river sand as bed soil. Each pot was irrigated with tap water for 133 days until the plants were well-established (observed dense leaves, and leaves height around $15 \mathrm{~cm}$ in each pot). During the tap water irrigation, no fertilizer was applied.

Four concentrations of $\mathrm{NaCl}$ solution were prepared [0 (as Control), 7.5, 15, and $30 \mathrm{~g} / \mathrm{L}$ ], with 3 repetitions. For the possibility of utilizing the plant in coastal area, the maximum concentration of the $\mathrm{NaCl}$ solution $(30 \mathrm{~g} / \mathrm{L})$ was set to sea water level, as referring previous experiment (Sugiura $e t$ al., 2017). The total number of pots prepared were 12 (4 concentrations of $\mathrm{NaCl}$ solution $\times 3$ repetitions). As for avoiding rain effects, each pot containing a plant was placed at random in a greenhouse (non-heated) at the Tokyo University of Agriculture, Tokyo, Japan.

\section{$2.2 \mathrm{NaCl}$ treatment}

After irrigating the pots with tap water for 133 days to establish the plants, $\mathrm{NaCl}$ solution was added. $\mathrm{NaCl}(99.5 \%)$ was mixed with tap water at the above-specified concentrations in plastic tanks. Thereafter, $600 \mathrm{~mL} \mathrm{NaCl}$ solution was used to treat to each pot from October 192015 to April 1 2016 (165 days). $\mathrm{NaCl}$ treatment was conducted when the soil surface was dry, including Oct. 19, Nov. 5 and 22, Dec. 9, 2015, Jan. 19, 2016 and Feb. 29, 2016 to yield six treatments. Tap water was not treated during the $\mathrm{NaCl}$ solution treatment period. To avoid adding $\mathrm{NaCl}$ treatment directly to $Z$. matrella leaves, a funnel was used, and $\mathrm{NaCl}$ solution was added directly to the soil. The average temperature and humidity in the non-heated greenhouse during $\mathrm{NaCl}$ solution treatment are illustrated in Fig. 1.

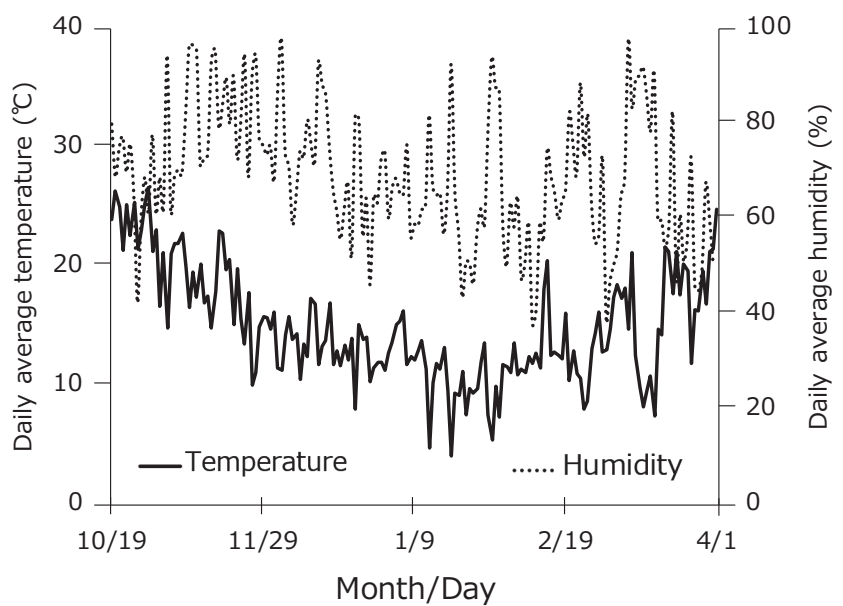

Fig. 1 Daily average greenhouse temperature and humidity during the $\mathrm{NaCl}$ treatment period

Data were measured from October 19, 2015 to April 1, 2016 (165 days). Greenhouse was not heated during experiment 
2.3 Measurement of leaf dry weight and leaf mortality ratio

After 165 days $\mathrm{NaCl}$ treatment, turf leaves were trimmed to a height of $2 \mathrm{~cm}$ from the soil surface to measure ion amount and dry weight (DW). To quantify dry weight, the leaves were dried in an oven at $90^{\circ} \mathrm{C}$ for $24 \mathrm{~h}$ and divided into green leaves and brown leaves, followed by measurement of biomass. The leaves were not washed with water prior to ion measurement in order to avoid ion outflow, especially in brown leaves (Japan Soil Association Ed., 2001). Therefore in the present study, the data regarding ion amounts include inside and outside ion of the leaves. Leaf mortality ratio was calculated using green leaf DW and brown leaf DW, according to the following formula:

\section{Leaf mortality ratio $(\%)=[$ brown leaf $\mathrm{DW} \div$ (green leaf $\mathrm{DW}$}

$$
+ \text { brown leaf DW) }] \times 100
$$

\subsection{Leaf ion measurement}

Dried leaves were milled using beads in a centrifuge tube with a homogenizer (BMS-A 20 TP, Bio Medical Science Co., Ltd., Tokyo, Japan). Measurement of ion amounts in the leaves was conducted as referring previous experiment (Russo \& Karmarkar, 1998). Milled dried leaves were transferred to a 2-mL centrifuge tube containing distilled water. The tube was then shaken thoroughly by hand for $30 \mathrm{sec}$., and the solution was subsequently filtered through a 0.45 $\mu$ m membrane filter (NY 025045, Membrane Solutions Limited). The quantities of each ion $\left(\mathrm{Na}^{+}, \mathrm{Cl}^{-}\right.$and $\left.\mathrm{K}^{+}\right)$were measured using an ion analyzer (IA-300, DKK-TOA Corporation, Tokyo, Japan).

2.5 Statistical analysis

Considering the small sample sizes (three repetitions) in this study, we used the nonparametric methods (Hoskin, 2010); Mann-Whitney U Test to evaluate significant differences between green and brown leaves, Bonferroni's multiple comparison test for comparison of four different $\mathrm{NaCl}$ treatments. Statistical analysis were conducted using the add-in analysis software in Microsoft Excel (BellCurve for Excel, Social Survey Research Information Co, Ltd.).

\section{Results and Discussion}

\subsection{Leaf dry weight and mortality ratio}

After 165 days $\mathrm{NaCl}$ treatment, green leaf dry weight was decreased according to $\mathrm{NaCl}$ concentrations treated. At 30 $\mathrm{g} / \mathrm{L}$, no green leaves remained (Table 1 ). However brown leaves dry weight did not differ between $\mathrm{NaCl}$ treatment groups. Leaf mortality ratios were $56.2,76.5,89.0,100 \%$ in ascending order of $\mathrm{NaCl}$ concentration.

The daily temperature in the green house was recorded below $5^{\circ} \mathrm{C}$ on January 13 (Fig. 1). At the end of the study, the control group, which was not subjected to $\mathrm{NaCl}$ stress, ex-
Table 1 Leaf dry weight and mortality ratio

Leaf mortality ratio was calculated using the following formula: Leaf mortality ratio $(\%)=$ [brown leaf $\mathrm{DW} \div$ (green leaf DW + brown leaf DW) $] \times 100$. Data were measured after 165 days $\mathrm{NaCl}$ treatment. Data are expressed as mean values \pm SD of triplicate analyses. Values sharing the same letter were not significantly different $(\mathrm{p}=0.05)$, as measured by a Bonferroni's multiple comparison test in comparison of four different $\mathrm{NaCl}$ treatments

\begin{tabular}{|c|c|c|c|c|}
\hline \multirow{2}{*}{$\begin{array}{l}\text { Treated } \mathrm{NaCl} \\
\text { solution } \\
\text { concentration } \\
\quad(\mathrm{g} / \mathrm{L})\end{array}$} & \multicolumn{3}{|c|}{ Leaf dry weight $\left(\mathrm{g} / 200 \mathrm{~cm}^{2}\right)$} & \multirow[b]{2}{*}{$\begin{array}{l}\text { Leaf mortality } \\
\text { ratio } \\
(\%)\end{array}$} \\
\hline & Green leaves & Brown leaves & $\begin{array}{l}\text { Green leaves } \\
\text { and } \\
\text { Brown leaves }\end{array}$ & \\
\hline Control & $1.9 \pm 0.5 \mathrm{a}$ & $2.6=$ & $4.5 \pm 1.7 \mathrm{a}$ & 56.2 \\
\hline 7.5 & $1.2 \pm 0.3 \mathrm{ab}$ & $4.4 \pm 1.7 \mathrm{a}$ & $5.6 \pm 1.8 \mathrm{a}$ & $76.5 \pm 9.6$ \\
\hline 15 & $0.4 \pm 0.1 \mathrm{bc}$ & $3.2 \pm 1.6 \mathrm{a}$ & $3.6 \pm 1.8 \mathrm{a}$ & $89.0 \pm 1.5$ \\
\hline 30 & $0.0 \pm 0.0 \mathrm{c}$ & $4.5 \pm 1.7 \mathrm{a}$ & $4.5 \pm 1.7 \mathrm{a}$ & $100.0 \pm 0.0$ \\
\hline
\end{tabular}

hibited a high mortality ratio of $56.2 \%$. This suggested that low temperature alone decreased green leaf dry weight, which was further exacerbated by salinity stress (Table 1). For the data of green leaves and brown leaves dry weight, there were no significant differences in all four $\mathrm{NaCl}$ treated groups (Table 1). Especially as the control (no- $\mathrm{NaCl}$ treated group) showed no significant difference, it was indicated that the low temperature halted leaves growing during the experiment in winter season.

\subsection{Leaf ion amounts}

In NaCl-stressed plants, both green and brown leaves showed large amounts of $\mathrm{NaCl}$. However, in brown leaves, $\mathrm{Na}^{+}$and $\mathrm{Cl}^{-}$amounts were higher than in green leaves [Fig. 2 (a), (b) ]. In the 7.5 and $15 \mathrm{~g} / \mathrm{L} \mathrm{NaCl}$ groups, $\mathrm{Na}^{+}$amounts in brown leaves were 1.4-fold and 2.0-fold higher significantly than in green leaves, respectively. Similarly, in the 7.5 and 15 $\mathrm{g} / \mathrm{L} \mathrm{NaCl}$ groups, $\mathrm{Cl}^{-}$amounts in brown leaves were 1.4-fold and 2.0-fold higher than in green leaves, respectively.

These results demonstrated that $Z$. matrella could accumulate large amounts of $\mathrm{NaCl}$ in senescing leaves, consistent with previous reports (Imada et al., 2009; Kanai et al., 2014). And it was considered that Zoysia matrella can remove $\mathrm{NaCl}$ by accumulating those ions in senescing leaves in a saline environment. However, in the salt tolerant plants, it was reported that the old cell develops vacuole to accumulate more salt in it (Takahashi, 1997, Maeda, 2012). Further study such as investigating relationship between leaves age and ion amounts in $Z$. matrella was considered in need.

Leaf $\mathrm{K}^{+}$amount exhibited a different trend than that of $\mathrm{Na}^{+}$and $\mathrm{Cl}^{-}$, with higher $\mathrm{K}^{+}$amount in green leaves relative to brown leaves (Fig. 2). In the 0 (Control), 7.5, and $15 \mathrm{~g} / \mathrm{L}$ $\mathrm{NaCl}$ groups, green leaves $\mathrm{K}^{+}$amounts were 2.3-fold, 1.8fold, and 1.8fold higher significantly than $\mathrm{K}^{+}$amount of 

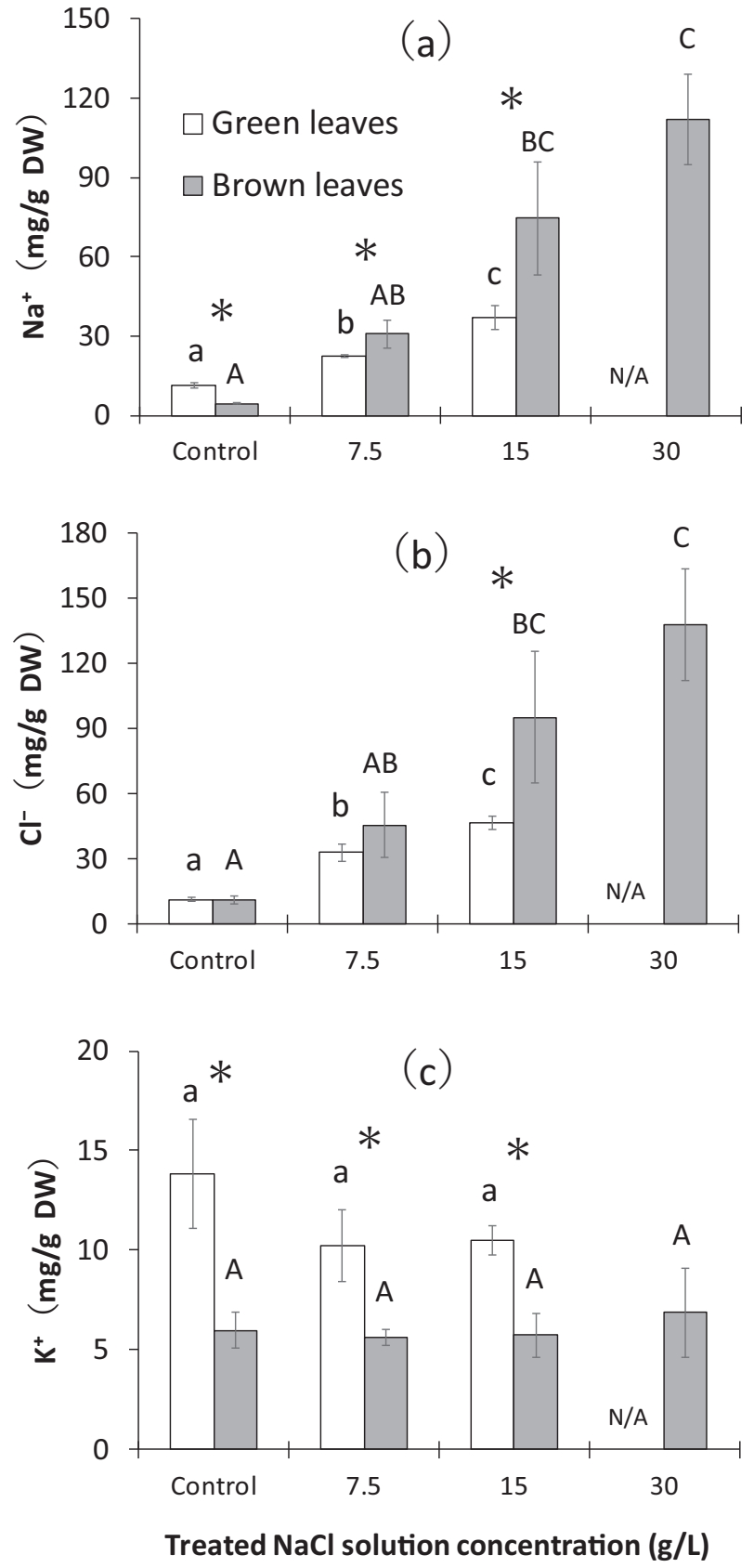

Fig. 2 Green leaves and brown leaves ion amounts (a) $\mathrm{Na}^{+}$, (b) $\mathrm{Cl}^{-}$, (c) $\mathrm{K}^{+}$. Ion amounts $\left(\mathrm{Na}^{+}, \mathrm{Cl}^{-}\right.$and $\mathrm{K}^{+}$) were measured after 165 days $\mathrm{NaCl}$ treatment. Data are expressed as means. Vertical bars represent SDs of triplicate analyses. Ion amounts include inside and outside ion of leaves. Statistically significant differences between green and brown leaves are denoted as: * $\mathrm{p}<0.05$. No mark denotes lack of statistical significance. Differences were assessed using a Mann-Whitney U Test. Values sharing the same letter were not significantly different $(p=0.05)$, as measured by a Bonferroni's multiple comparison test in comparison of four different $\mathrm{NaCl}$ treatments. Small letter: green leaves, large letter: brown leaves. All leaves were observed as brown leaves in the 30 $\mathrm{g} / \mathrm{L} \mathrm{NaCl}$ treated condition, indicated as $\mathrm{N} / \mathrm{A}$ brown leaves, respectively. The results of the present study suggest that during the winter season, $Z$. matrella is capable of translocating $\mathrm{K}^{+}$from senescing leaves to other parts of the plant prior to the leaves' dying as previously reported in Quercus serrata (Hiraizumi et al., 1996). Moreover, most of potassium remains as ion in the plant cells and not be transformed other substances (Nakamura Ed., 1993). Those reports and low $\mathrm{K}^{+}$amount of brown leaves in the present study results [Fig. 2(c)] suggested our consideration. However, for more detail on ion accumulate trait in leaves, additional experiment such as using isotope tracking techniques was considered in need.

$3.3 \mathrm{~K}^{+} / \mathrm{Na}^{+}$ratio of green and brown leaves.

$\mathrm{K}^{+} / \mathrm{Na}^{+}$ratio (mass value) in both green and brown leaves showed low value accordance with treated $\mathrm{NaCl}$ concentration increased. However, the green leaves showed higher value compared with brown leaves with significant difference in $7.5 \mathrm{~g} / \mathrm{L}$ (2.4-fold higher) and $15 \mathrm{~g} / \mathrm{L}$ (3.5-fold higher) $\mathrm{NaCl}$ solution treated groups (Table 2).

Usually, plants in the salinity stress lose $\mathrm{K}^{+}$with inclusion of $\mathrm{Na}^{+}$in the cell, that phenomenon accelerates salt stress. In salt tolerant plants, it was reported $\mathrm{K}^{+}$retention in the cell in the salinity stress, and the $\mathrm{K}^{+} / \mathrm{Na}^{+}$ratio is important indicator for evaluating salt tolerance in plant (Schachtman et al., 1989; Takahashi, 1997; Maeda, 2012). For one of the salinity tolerance mechanism in Zoysia species is related to $\mathrm{Na}^{+}$compartment in vacuole, and it was functioned by

Table $2 \mathrm{~K}^{+} / \mathrm{Na}^{+}$ratio (mass value) of green and brown leaves against four different concentration of $\mathrm{NaCl}$ solution treatment

Data were measured after 165 days $\mathrm{NaCl}$ treatment. Data are expressed as mean values $\pm \mathrm{SD}$ of triplicate analyses. Ion amounts include inside and outside ion of leaves. Statistically significant differences between green and brown leaves are denoted as: ${ }^{*} \mathrm{p}<0.05$, ns denotes lack of statistical significance. Differences were assessed using a Mann-Whitney U Test. Values sharing the same letter were not significantly different $(p=0.05)$, as measured by a Bonferroni's multiple comparison test in comparison of four different $\mathrm{NaCl}$ treatments. All leaves were observed as brown leaves in the $30 \mathrm{~g} / \mathrm{L} \mathrm{NaCl}$ treated condition, indicated as $\mathrm{N} / \mathrm{A}$

\begin{tabular}{cccc}
\hline $\begin{array}{c}\text { Treated } \mathrm{NaCl} \\
\text { solution } \\
\begin{array}{c}\text { concentration } \\
(\mathrm{g} / \mathrm{L})\end{array}\end{array}$ & Green leaves & Brown leaves & $\begin{array}{c}\text { Significant } \\
\text { differences }\end{array}$ \\
\cline { 2 - 4 } Control & $1.26 \pm 0.41 \mathrm{a}$ & $1.32 \pm 0.22 \mathrm{a}$ & $\mathrm{ns}$ \\
7.5 & $0.46 \pm 0.10 \mathrm{~b}$ & $0.19 \pm 0.06 \mathrm{~b}$ & $*$ \\
15 & $0.28 \pm 0.02 \mathrm{~b}$ & $0.08 \pm 0.02 \mathrm{~b}$ & $*$ \\
30 & $\mathrm{~N} / \mathrm{A}$ & $0.06 \pm 0.01 \mathrm{~b}$ & $\mathrm{~N} / \mathrm{A}$ \\
\hline
\end{tabular}


$\mathrm{Na}^{+} / \mathrm{H}^{+}$antiporter on bio membrane (Du et al., 2010; Chen et al., 2015).

The results of ion amount and $\mathrm{K}^{+} / \mathrm{Na}^{+}$ratio in the present study indicated completely different with green and brown leaves (Fig. 2, Table 2). From the results of the present study and previous reports, for one of the salt tolerance mechanism of $Z$. matrella in winter season, it was considered that the senescing leaves has important role for accumulation of harmful salinity in the senescing leaves against salinity stress.

\section{References}

Akamine, H., Ishimine, Y., Kurihara, N., Omokawa, H., Ichizen, N. and Kuramoch, H. (2002) Influence of Salinity on the Growth, and Na, K and Amino Acid Contents in Mascarenegrass (Zoysia tenuifolia Willd.). Journal of Japanese Society of Turfgrass Science 31(1): 2-6 (in Japanese).

Asano, Y. and Namihisa, H. (1999) Growth Responses to Salinity in Zoysiagrasses. Journal of Japanese Society of Turfgrass Science, 28(1): 42-44 (in Japanese).

Chen, J., Yan J., Qian, Y., Jiang, Y., Zhang, T., Guo, H., Guo, A. and Liu, J. (2009) Growth Responses and Ion Regulation of Four Warm Season Turfgrasses to Long-Term Salinity Stress. Scientia Horticulturae 122(4): 620-625.

Chen, Y., Li, L., Zong, J., Chen, J., Guo, H., Guo, A. and Liu, J. (2015) Heterologous Expression of the Halophyte Zoysia matrella $\mathrm{H}+$ - Pyrophosphatase Gene Improved Salt Tolerance in Arabidopsis thaliana. Plant Physiology and Biochemistry 91: 49-55.

Du, Y., Hei, Q., Liu, Y., Zhang, H., Xu, K. and Xia, T. (2010) Isolation and Characterization of a Putative Vacuolar $\mathrm{Na}+/ \mathrm{H}+$ Antiporter Gene from Zoysia japonica L. Journal of Plant Biology 53(4): 251-258.

Fukuoka, H. (2000) Breeding of Zoysia Grass 1. Collection of Genetic Resources and General View of Their Characteristics. Journal of Japanese Society of Turfgrass Science, 29 (1): 11-21 (in Japanese).

Hiraizumi, S., Kawaguchi, J. and Tadaki, Y. (1996) The Return of Nutrients with Litter-fall in Some Secondary Forests in Nagoya. Bulletin of the Nagoya University Forests, 15: 123140 (in Japanese).

Hoskin, T. (2010) Parametric and Nonparametric: Demystifying the Terms. Ctsa. Mayo. Edu. 1-5.

Imada, S., Yamanaka, N. and Tamai, S. (2009) Effects of Salinity on the Growth, Na Partitioning, and Na Dynamics of a Salttolerant Tree, Populus alba L. Journal of Arid Environments, 73(3): 245-251.

Japan Soil Association (Edited) (2001) The Methods of Soil, Water and Plant Analysis. 321 pp. Japan Soil Association, Tokyo (in Japanese).
Kanai, H., Tajima, M. and Sakai, A. (2014) Effects of Salinity on the Growth and Survival of the Seedlings of Mangrove, Rhizophora stylosa. International Journal of Plant \& Soil Science, 3(7): 879-893.

Maeda, Y. (2012) Plant Salt Tolerance and Removal of Salt in Saline Soil by Plants. Bulletin of the Society of Sea Water Science, Japan 66(2): 92-98.

Marcum, K.B. (2006) Use of Saline and Non-Potable Water in the Turfgrass Industry: Constraints and Developments. Agricultural Water Management, 80(1-3 SPEC. ISS.): 132146.

Marcum, K.B. and Murdoch, C.L. (1994) Salinity Tolerance Mechanisms of Six C 4 Turfgrasses. Journal of the American Society for Horticultural Science 119(4): 779-784.

Nakamura, N. (Edited) (1993) ZOYSIAGRASS: Science and Management for Golf Course. 368 pp. Soft Science, Inc., Tokyo (in Japanese).

Russo, V.M. and Karmarkar, S.V. (1998) Water Extraction of Plant Tissues for Analysis by Ion Chromatography. Communications in Soil Science and Plant Analysis, 29(3-4): $245-253$.

Sato, S. (1995) Physio-Ecologocal Charactors of Cool and Warm Season Turfgrass. Journal of Japanese Society of Turfgrass Science 23(2): 145-157 (in Japanese).

Schachtman, D.P., Bloom, A.J. and Dvorak, J. (1989) Salt-tolerant Triticum $\times$ Lophopyrum Derivatives Limit the Accumulation of Sodium and Chloride Ions under Saline-stress. Plant, Cell and Environment 12: 47-55.

Sugiura, S. (2020) Salt Gland Characteristics and Activity of Zoysia matrella Merr. in Environments with Different Levels of Salinity. Journal of Japanese Society of Turfgrass Science 48(2): 142-148.

Sugiura, S., Tanaka, S., Mizuniwa, C. and Takahashi, S. (2017) Mitigation of Salt Accumulation in Soil by Zoysia matrella Merr. Journal of Japanese Society of Turfgrass Science, 45 (2): 103-107 (in Japanese).

Takahashi, E. (1997) What Is Salt for Biosis -Salt Excessive for the Soil and Diet- (2 nd Edition). 201 pp. Rural Culture Association Japan, Tokyo (in Japanese).

Turgeon, A.J. (2007) Turfgrass Management (8 th Edition). 436 pp. Prentice Hall, New Jersey.

Uddin, M.K., Juraimi, A.S., Ismail, M.R., Othman, R. and Rahim, A.A. (2009) Growth Response of Eight Tropical Turfgrass Species to Salinity. African Journal of Biotechnology, 8(21): 5799-5806.

Yamamoto, A., Hashiguchi, M., Akune, R., Masumoto, T., Muguerza, M., Saeki, Y. and Akashi, R. (2016) The Relationship between Salt Gland Density and Sodium Accumulation/Secretion in a Wide Selection from Three Zoysia Species. Australian Journal of Botany 64(4): 277-284.

(Accepted: August 18, 2020) 